\title{
街路樹による $\mathrm{NO}_{2}$ の吸収と葉からの転流について
}

\author{
三沢 彰*・二葉恵美 $* * \cdot N$. ニザール***・立本英機 $* * * *$
}

\section{Transport of $\mathrm{NO}_{2}$ Absorbed by Leaves of Roadside Trees}

\author{
Misawa, Akira*, Hutaba, Emi**, Nasrullah, Nizar***, Tatsumoto, Hideki****
}

\section{1. はじめに}

$\mathrm{NO}_{2}$ は直接人体に有害であるだけでなく, 酸性雨の原 因物質としても最近注目されている大気污染物質であ る。植物がこのようなガス状大気污染物質を葉から吸収 することは古くから研究され, 多くの植物の吸収速度や 能力について明らかにされている。しかし, $\mathrm{NO}_{2}$ の吸収 についてはほとんどがトマト4), インゲンマメ4), ヒマワ リ $^{4)}$, アルファルファ ${ }^{1)}$ な゙の草本植物についての研究で あった。近年都市部を中心に自動車排出ガスによる $\mathrm{NO}_{2}$ 濃度の増加傾向が見られ, 街路樹によって沿道の大気浄 化をはかるため木本植物による $\mathrm{NO}_{2}$ の吸収に関する研 究がなされるようになった。しかしその $\mathrm{NO}_{2}$ の吸収の定 量は葉中の窒素含有量から求められており, 葉からの転 流は考慮されていない。一方植物の葉から吸収された $\mathrm{NO}_{2}$ の転流に関する研究は安定同位元素 ${ }^{15} \mathrm{~N}$ を用いて 行われているが, それもヒマワリ5), ホウレンソウ2)など の草本植物を用いた研究のみである。木本植物について は果樹の葉面に行う尿素肥料の施肥に関しての研究3) が あるのみである。そこで街路樹に多く用いられている樹 木を用いて, 葉から吸収された $\mathrm{NO}_{2}$ の転流量の測定を試 みた。なお, 転流の速度は以前は色素などを用いて調べ られていたが, 近年ではアイソトープを用いてかなり正 確に転流の速度が計れるようになった。

* 千葉大学園芸学部 Faculty of Horticulture, Chiba Univ.

** 地域開発研究所 Institute of Regional Development

*** 千葉大学大学院自然科学研究科環境科学専攻 Department of Environmental Sciences, Graduate School of Science and Technology, Chiba Univ.

**** 千葉大学工学部 Faculty of Engineering, Chiba Univ.

\section{2. 実験方法}

\section{1 供試植物}

一般に街路樹に多く用いられているものの中から次の 5 種を選んだ。

クスノキ (Cinnamomum camphora Sieb.)

マテバシイ (Lithocarpus edulis Nakai)

ヤマモモ (Myrica rubra Sieb. et Zucc.)

イチョウ (Ginkgo biloba L.)

ソメイヨシノ (Prunus yedoensis Matsumura)

供試植物は 1 樹種につき15個体用意し 1 個体ずつ直径 $25 \mathrm{~cm}$, 深さ $27 \mathrm{~cm}$ のプラスチックポットに移植した。土 は山土を用い, 肥料は与えなかった。灌水は毎日行った。 移植後 2 週間ほど養生をし, 成育が良好な 8 個体を選び 暴露実験に供した。供試樹木の平均形状を表 1 に示した。

\section{$2.2{ }^{15} \mathrm{NO}_{2}$ 暴露}

${ }^{15} \mathrm{NO}_{2}$ の暴露には図 1 に示す同化箱を用いた。この同 化箱に 1 個体ずつプラスチックポットより上の部分を入 れ,ウレタン製スポンジで幹の周囲を目張りし密閉した。 同化箱内の空気は内部に設置した 2 個のファンにより絶 えず攪汼した。この同化箱内に ${ }^{15} \mathrm{~N}$ 標識の ${ }^{15} \mathrm{NO}_{2}$ ガス （99 atom\% $15 \mathrm{~N}$ ) を注入し120分間暴露した。同化箱内 の ${ }^{15} \mathrm{NO}_{2}$ 濃度はガステックおよび検知管で測定した。 ${ }^{15} \mathrm{NO}_{2}$ ガスは最初に注入した後は補充しなかった。表 2 にクスノキを例に暴露環境 $\left(\mathrm{NO}_{2}\right.$ 濃度, 気温, 同化箱内 気温，日射量）を示したが，他の樹種についてもほほ同 様の暴露環境で実験を行った。

暴露期間中および終了後も葉面に可視的障害は発生し なかった。暴露した植物 8 個体のうち 2 個体は暴露終了 後直ちに葉(葉柄部を含む), 幹, 根に切り分け採取した。 同様に 2 個体ずつ暴露終了後 $7,14,28$ 日目に葉, 幹, 


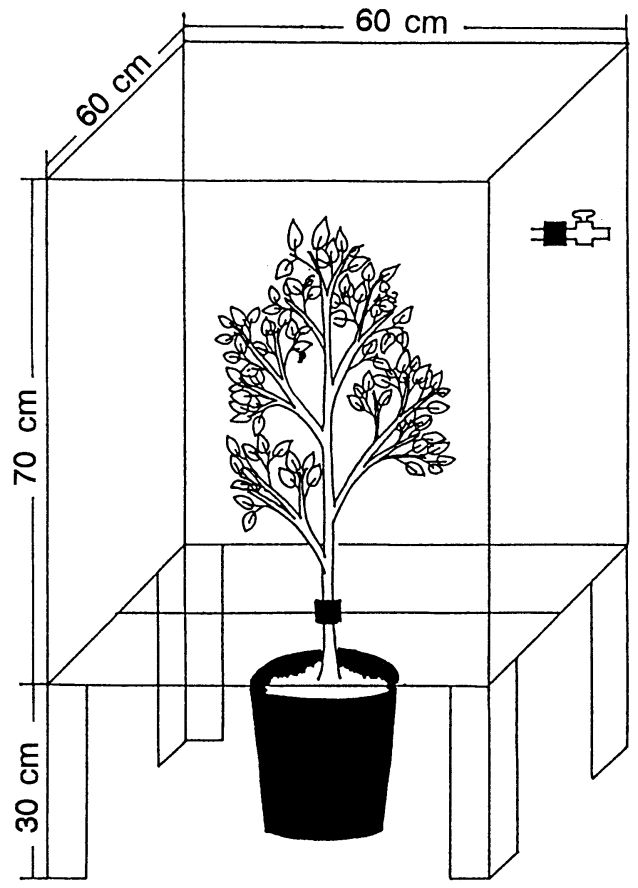

図 1 同化箱の形状
根に分け採取した。根は土を洗い落とし24時間自然乾燥 させ, 葉は自動葉面積計で面積を測定した。葉, 幹, 根 とも生重を計り, 摂氏 80 度で 2 日間乾燥した後, 乾重を 計り, 粉砕器で粉砕した。

\section{$2.3^{15} \mathrm{~N}$ の定量}

全空素の定量

粉砕した試料を $500 \mathrm{mg}$ 計り取り, 分解促進剤(硫酸マ グネシウム：硫酸銅=9：1） $3 \mathrm{~g}$ と濃硫酸 $5 \mathrm{ml}$ とともに 3 時間加熱分解した。分解後 $30 \%$ 水酸化ナトリウム溶液 を $15 \mathrm{ml}$ 加え, $\mathrm{N} / 10$ 硫酸溶液 $10 \mathrm{ml}$ を受器とし, クロロフ エノールレッドを指示薬として蒸留をした。蒸留後 N/ 10水酸化ナトリウムで滴定をし，全窒素量を定量した。

$\bigcirc$ 再蒸留

前項で滴定した試料に $10 \%$ 水酸化ナトリウム溶液を 5 滴加え, $20 \mathrm{ml}$ のサンプル瓶を受器として $2 \mathrm{~N} / 10$ 塩酸受 けで再蒸留をした。この塩酸の量は試料中の全窒素量に 応じて次式に従って変えた。

$2 \mathrm{~N} / 10$ 塩酸量 $(\mathrm{ml})=$ 試料中の全窒素量 $(\mathrm{mg}) \times 0.7 \times 1 / 3$ 再蒸留した試料は $105^{\circ} \mathrm{Cで}$ 乾燥, 結晶化させた後, 希釈 した。

このようにして調整した試料を放電管に封入し, 高周 波ガス化装置にかけ発光させてそのピークを $15 \mathrm{~N}$ アナ

表 1 供試樹種の形状（8 個体の平均值）

\begin{tabular}{|c|c|c|c|c|c|c|c|c|c|c|}
\hline \multirow[b]{2}{*}{ 供試樹種 } & \multirow[b]{2}{*}{$\begin{array}{l}\text { 樹高 } \\
(\mathrm{cm})\end{array}$} & \multirow[b]{2}{*}{$\begin{array}{l}\text { 葉幅 } \\
(\mathrm{cm})\end{array}$} & \multirow[b]{2}{*}{$\begin{array}{c}\text { 着葉数 } \\
\text { (枝) }\end{array}$} & \multirow[b]{2}{*}{$\begin{array}{l}\text { 葉面積 } \\
\left(\mathrm{cm}^{2}\right)\end{array}$} & \multicolumn{2}{|c|}{ 生 } & 重 & \multicolumn{2}{|c|}{ 乾 } & 重 \\
\hline & & & & & $\begin{array}{l}\text { 葉 } \\
(\mathrm{g})\end{array}$ & $\begin{array}{l}\text { 幹 } \\
(\mathrm{g})\end{array}$ & $\begin{array}{l}\text { 根 } \\
(\mathrm{g})\end{array}$ & $\begin{array}{l}\text { 葉 } \\
(\mathrm{g})\end{array}$ & $\begin{array}{l}\text { 幹 } \\
(\mathrm{g})\end{array}$ & $\begin{array}{l}\text { 根 } \\
(\mathrm{g})\end{array}$ \\
\hline クスノキ & 87.3 & 51.8 & 226.4 & 2475.1 & 53.9 & 53.3 & 103.3 & 22.8 & 24.1 & 43.2 \\
\hline マテバシイ & 95.0 & 35.0 & 53.5 & 1624.0 & 42.9 & 45.1 & 45.4 & 20.8 & 23.1 & 28.1 \\
\hline ヤマモモ & 97.3 & 38.1 & 143.1 & 1581.2 & 33.7 & 56.6 & 40.7 & 14.7 & 25.5 & 20.8 \\
\hline イチョウ & 112.0 & 21.8 & 53.9 & 774.0 & 16.0 & 48.7 & 58.7 & 5.2 & 22.1 & 23.4 \\
\hline ソメイヨシノ & 141.0 & 25.9 & 70.9 & 784.3 & 16.9 & 91.6 & 51.8 & 6.2 & 45.2 & 23.7 \\
\hline
\end{tabular}

表 2 暴露環境（クスノキ）

\begin{tabular}{|c|c|c|c|c|c|c|c|}
\hline 個体 No. & 暴露日 & $\begin{array}{c}{ }^{15} \mathrm{NO}_{2} \text { 濃度 }{ }^{\mathrm{a}} \\
(\mathrm{ppm})\end{array}$ & $\begin{array}{c}\text { 気温b } \\
\left({ }^{\circ} \mathrm{C}\right)\end{array}$ & $\begin{array}{c}\text { 同化箱内気温 }{ }^{b} \\
\left({ }^{\circ} \mathrm{C}\right)\end{array}$ & $\frac{\text { 湿度 }^{\mathrm{b}}}{(\%)}$ & $\begin{array}{c}\text { 同化箱内湿度 } \\
(\%)\end{array}$ & $\left(\times \begin{array}{l}\text { 照度 } \\
\text { 100 lux }\end{array}\right.$ \\
\hline $0-\mathrm{A}$ & $8 / 18$ & 2.0 & 30.0 & 33.0 & 69.7 & 80.0 & 180.6 \\
\hline $0-\mathrm{B}$ & $8 / 18$ & 2.0 & 30.0 & 34.0 & 69.7 & 80.0 & 159.7 \\
\hline $7-\mathrm{A}$ & $8 / 16$ & 1.5 & 32.0 & 34.0 & 69.0 & 80.0 & 150.7 \\
\hline $7-B$ & $8 / 16$ & 1.5 & 32.0 & 34.0 & 70.0 & 82.0 & 194.7 \\
\hline $14-\mathrm{A}$ & $8 / 11$ & 1.5 & 33.0 & 34.5 & 68.0 & 80.7 & 83.2 \\
\hline $14-\mathrm{B}$ & $8 / 11$ & 2.0 & 31.5 & 34.0 & 75.3 & 81.0 & 159.0 \\
\hline $28-\mathrm{A}$ & $7 / 20$ & 3.5 & 30.0 & 32.3 & 69.7 & 76.3 & 75.0 \\
\hline $28-\mathrm{B}$ & $7 / 21$ & 1.5 & 30.3 & 32.7 & 71.3 & 84.0 & 105.0 \\
\hline
\end{tabular}

$\mathrm{a}$ ：暴露開始時の值

$\mathrm{b}$ : 暴露開始時, 1 時間後, 暴露終了時の值の平均 


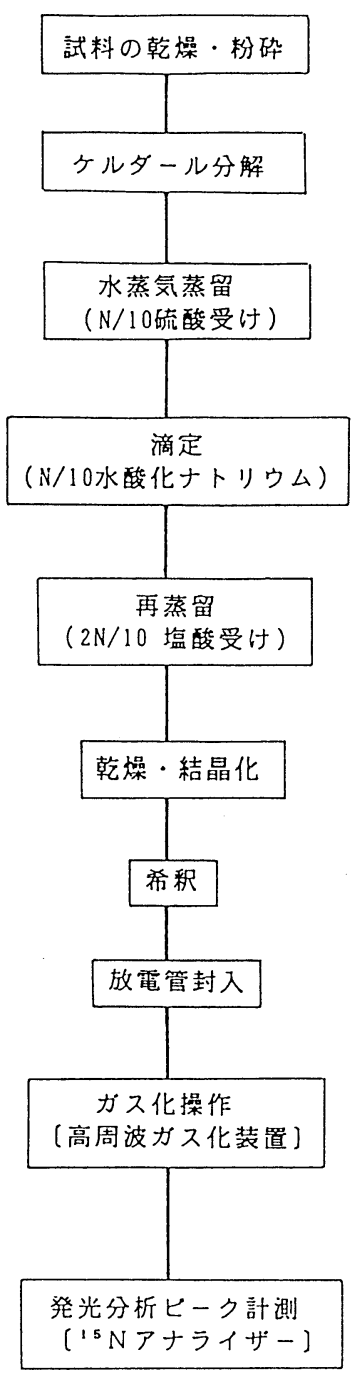

全公素量定量

${ }^{15} \mathrm{~N}$ atom\% 計算

図 $2{ }^{15} \mathrm{~N}$ 濃度分析の流れ

ライザーで計測した。以上の分析方法の流れを図 2 に示 した。

\section{3. 結果および考察}

分析によって求められた試料中の ${ }^{15} \mathrm{~N}$ の存在率 $\left({ }^{15} \mathrm{~N}\right.$ atom\%) には自然存在比（natural ${ }^{15} \mathrm{~N}$ atom\%) の0.367 atom\%が含まれている。従ってこれを差し引いて自然存 在比以上に存在する ${ }^{15} \mathrm{~N}\left({ }^{15} \mathrm{~N}\right.$ atom\% excess) を求めた。 試料中の ${ }^{15} \mathrm{~N}$ atom $\%$ excess, $\mathrm{NO}_{2}$ 由来の ${ }^{15} \mathrm{~N}$ を求 め, 暴露終了直後, $7,14,28$ 日後の各時点における葉, 幹, 根への ${ }^{15} \mathrm{~N}$ の分配割合を求め図 $3 \sim 7$ に示した。図 中 $\mathrm{A}, \mathrm{B}$ は各時点での試料木 2 個体を識別するために便

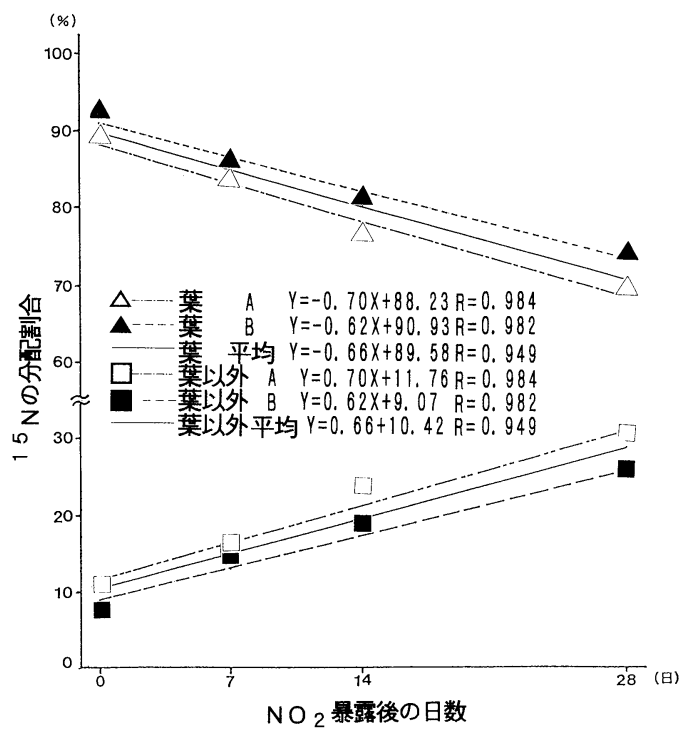

図 3 クスノキの葉と葉以外への ${ }^{15} \mathrm{~N}$ の分配割合

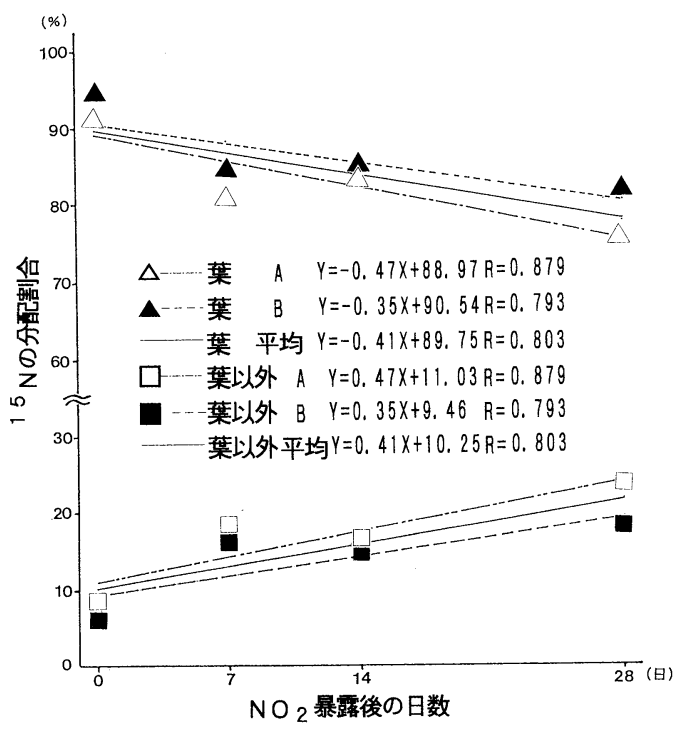

図 4 マテバシイの葉と葉以外への ${ }^{15} \mathrm{~N}$ の分配割合

宜的につけたものであるが, A， Bの差はクスノキ，マ テバシイ, ヤマモモの葉で約 $5 \%$, イチョウ, ソメイヨ シノの葉で約 $2 \% に$ 過ぎない。また, 幹, 根ではいずれ も $2 \%$ 以下であった。

暴露終了直後には 5 樹種とも $90 \%$ 以上の ${ }^{15} \mathrm{~N}$ が葉に 含まれているがその後徐々に減少している。すなわち時 間経過とともに葉中の ${ }^{15} \mathrm{~N}$ の配分割合が減少した。反対 


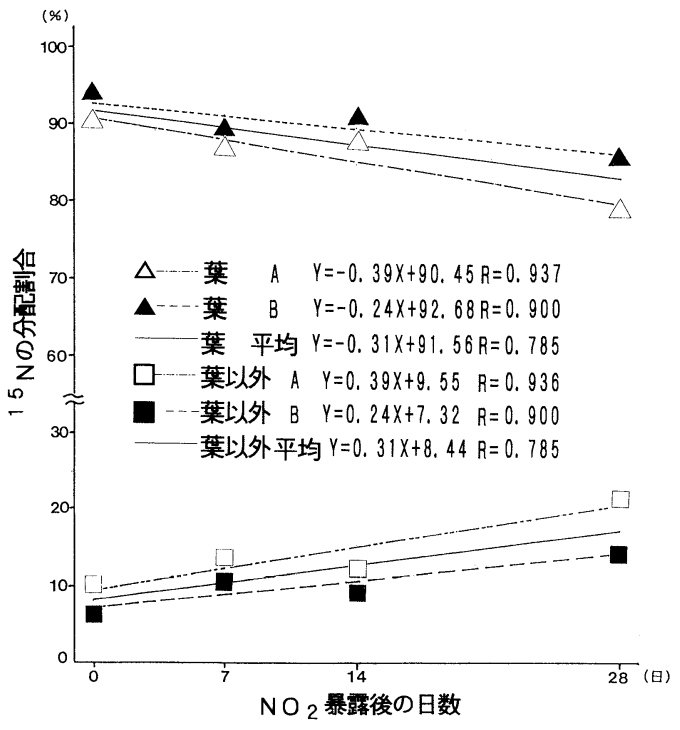

図 5 ヤマモモの葉と葉以外への ${ }^{15} \mathrm{~N}$ の分配割合

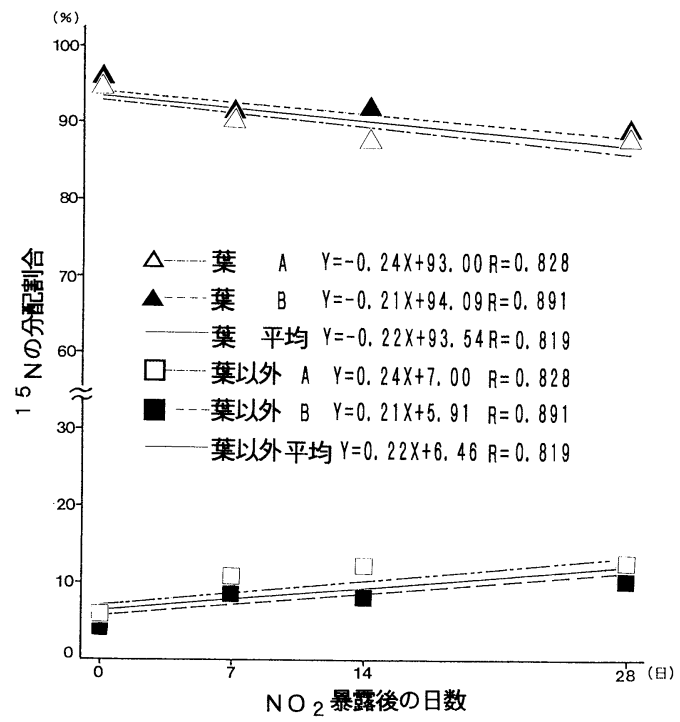

図 6 イチョウの葉と葉以外への ${ }^{15} \mathrm{~N}$ の分配割合

に幹，根の中の ${ }^{15} \mathrm{~N}$ は増加した。米山らによるヒマワリ の成熟葉からの窒素と炭素の研究では, 炭素の大部分は 24 時間以内に暴露葉から他の部位に転流しているが，窒 素は最初の 24 時間以内にやや急激に転流するが, その後 は徐々に転流する。また, 成熟葉で吸収された窒素は幼 葉や根などの生育中の部位に転流しているとしてい る ${ }^{3)}$ 。また, 岡野らはヒマワリの成熟葉 1 枚に ${ }^{15} \mathrm{NO}_{2}$ を暴 露し, 植物体内での ${ }^{15} \mathrm{~N}$ の移動について実験を行ってい

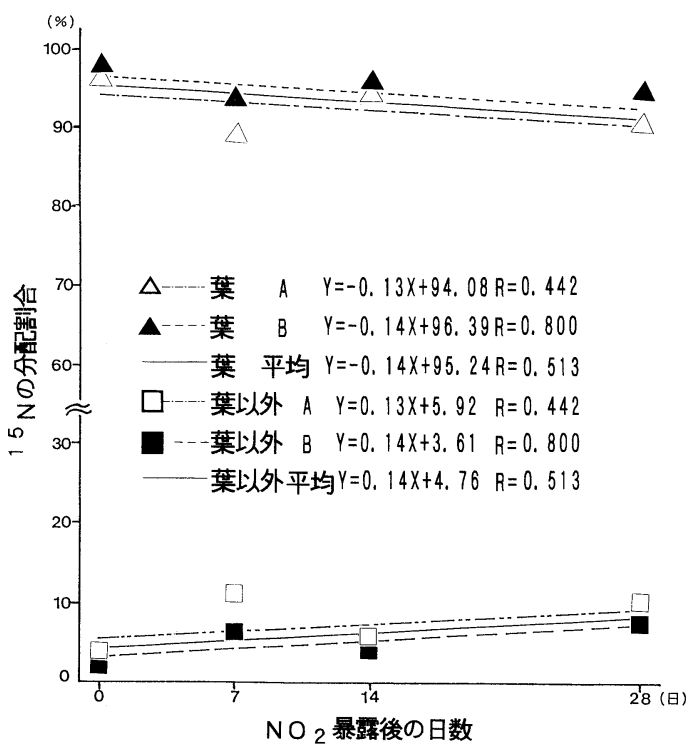

図 7 ソメイヨシノの葉と葉以外への ${ }^{15} \mathrm{~N}$ の分配割合

る。これによると ${ }^{15} \mathrm{~N}$ はまず上下の通道組織に見出さ れ, ついで生育中の器官（新葉と根）に転流するが, 成

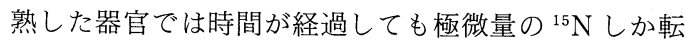
流しない。転流を支配する内的要因の一つとして代謝特 性があげられる,としている4)。今回の供試樹種中, 転流 割合はクスノキが最も多く, 暴露終了後 28 日目には約 30 $\%$ の ${ }^{15} \mathrm{~N}$ が葉から転流しており，ついでマテバシイー 22 \%, ヤマモモ-18\%, イチョウー $13 \%$, ソメイヨシノー $9 \%$ の順になっている。このように常緑樹のほうが落葉 樹よりも窒素分の転流が多い傾向が示唆された。これは 常緑樹の場合は当年葉以外にすでに成熟した 2 年葉を持 ちそれらが吸収した窒素は枝幹, 根の生育に利用するこ とができるが落葉樹の場合全葉が当年葉なのでそれ自身 の生育に多くの窒素を必要としたためと考えられる。

以上の結果から計算すると 1 日当りの窒素の転流割合 はクスノキー0.62-0.70\%，マテバシイー0.35-0.47\%， ヤマモモー0.24-0.39\%, イチョウー0.21-0.24\%, ソメ イヨシノ - $0.13-0.14 \%$ となり, これを従来の窒素含有量 から求める樹葉による $\mathrm{NO}_{2}$ 吸収量の計算に加える必要 があり，1 か月当たり，常緑樹で10-20\%，落葉樹で10\% 程度の割り増しを考慮することが妥当であると考えられ た。

本研究を行うにあたつて, 特に ${ }^{15} \mathrm{~N}$ の分析についてご 指導, ご協力をいただいた昭光通商株式会社の村岡研一 氏に深甚の謝意を表します。 


\section{引用文献}

1) HiLl, A.C ; Vegetation A sink for atmospheric pollutants. J. Air Pollt. Control Assoc. 21, 341-436, 1971

2) KajI, M, Yoneyama, T, TOTSUKA, T and IwAKI, $\mathrm{H}$; Absorption of atmospheric $\mathrm{NO}_{2}$ absorption in the leaves and transfer of the nitrogen through the plants. Res. Rep. Narl. Environ. stud. No. 11, 51-58, 1980
3）鎌倉武富；理論と実際 尿素肥料詳説, 社団法人大日本 農会編，143-156，1956

4）岡野邦夫; ${ }^{15} \mathrm{~N}$ 希釈法による植物の $\mathrm{NO}_{2}$ 吸収能の評価, 国立公害研究所報告 No. 108，89-101，1987

5) Yoneyama, T, ARAI, $T$ and TotsukA, $T$; Transfer of nitrogen and carbon from mature sunflower leaf ${ }^{15} \mathrm{NO}_{2}$ and ${ }^{13} \mathrm{CO}_{2}$ feeding studies. Plant \& Cell Physiol. 21 (8), 1367-1381, 1980

(1993.8.3 受理) 